\title{
The European Court of Human Rights, Transitional Justice and Historical Abuse in Consolidated Democracies
}

\section{James Gallen*}

\section{ABSTRACT:}

In recent years, both transitional justice and the role of the European Court of Human Rights in dealing with historical abuses have evolved. Transitional justice has begun to address widespread or systemic human rights abuses outside of the contexts of armed conflict and authoritarian regimes. In three key recent decisions, El-Masri $v$ Macedonia, Janowiec $v$ Russia and O'Keeffe $v$ Ireland, the European Court of Human Rights has clarified and expanded its approach to addressing historical human rights violations relevant to transitional justice in significant, if inconsistent, ways. To date, there is no exploration of the relationship between transitional justice, historical abuse outside the contexts of armed conflict or authoritarian rule and the European Convention of Human Rights. This article seeks to address that gap. This article considers the potential opportunities and obstacles for the use of the Convention to address historical abuse in consolidated democracies as part of transitional justice.

Word-Count: 15351

\section{KEYWORDS:}

Transitional justice, historical abuse, inter-temporal international law, Articles 2 and 3 European Convention on Human Rights, torture, inhuman or degrading treatment.

\section{INTRODUCTION}

In three key recent decisions, the European Court of Human Rights (the Court) has clarified and expanded its approach to addressing historical human rights violations relevant to transitional justice in significant, if inconsistent, ways. In 2012, in El-Masri $v$ Macedonia, ${ }^{1}$ the Court made its first explicit reference to the right to truth, expanding

*Assistant Professor, School of Law and Government, Dublin City University -(james.gallen@dcu.ie). ${ }^{1}$ El-Masri v Macedonia, Application No 39630/09, Merits and Just Satisfaction-Judgment,13 December 2012.
Formatted: Left

Formatted: Font: Not Bold

Formatted: Font: Not Bold
Formatted: Font: Not Italic

Formatted: Font: Not Italic

Formatted: Font: Not Italic

Formatted: Font: Not Italic 
the legal expression and regulation of transitional justice by the European Convention on Human Rights ('the Convention'). ${ }^{2}$ In Janowiec $v$ Russia, the Court clarified its historical methodology, limiting the potential application of the Convention to ten years before the date of ratification for states parties and, for cases involving the violation of the underlying values of the Convention, the date of the adoption of the Convention itselflimiting the potential application of the Convention to ten years from the date of ratification for states parties and in general to the date of the adoption of the Gonvention itself. ${ }^{3}$ In 2014, in O'Keeffe $v$ Ireland the Court affirmed that Ireland violated an historical obligation in 1973 under Article 3 of the Convention to prevent and punish child sexual abuse in a primary school privately operated by the Catholic Church. ${ }^{4}$ These decisions can be viewed as clarifying the law applicable to an expansionary trend in transitional justice, extending to European consolidated democracies and addressing legacies of gross violations of human rights outside the contexts of armed conflict or authoritarian rule. Transitional justice can be understood as the full range of processes and mechanisms employed by a society to reckon with a past legacy of gross violations of human rights, in particular, genocide, war crimes and crimes against humanity. ${ }^{5}$ To date, it has primarily concerned post-conflict and post-authoritarian societies. In these settings, the Convention and the Court have played a valuable role in the regional development of norms and legal standards regulating how member states of the Council of Europe address legacies of gross violations of human rights. ${ }^{6}$

However, in recent years, both transitional justice and the role of the European Court of Human Rights in dealing with historical abuses have evolved. Transitional justice scholarship and practice has begun to address widespread or systemic human rights abuses outside of the contexts of armed conflict and authoritarian regimes, and to

\footnotetext{
${ }^{2}$ Convention for the Protection of Human Rights and Fundamental Freedoms 1950, GETS 5.

${ }^{3}$ Janowiec and Others v Russia Application aNo 55508/07, Merits and Just Satisfaction-Grand Chamber Judgment, 21 October 2013, at paras 140-151 [Grand Chamber].

${ }^{4}$ O'Keeffe v Ireland, Judgment, Application $\mathrm{ANN}$ 35810/09, Merits and Just Satisfaction _, 28th January 2014 [Grand Chamber]. See Gallen, 'O'Keeffe v Ireland: The Liability of States for Failure to Provide an Effective System for the Detection and Prevention of Child Sexual Abuse in Education' (2015) 78_The Modern Law Review 151.

5 'United Nations Security Council ${ }_{1=}$ Report of the Secretary-General on the Rule of Law and

Transitional Justice in Conflict and Post-Conflict Societies, (S/2004/616), 3 -August 3 2004.'

6 Ní Aoláin, 'Transitional Justice and the European Convention on Human Rights' (2017) Geneva

Academy Briefing No. 10, available at: https://www.geneva-academy.ch/news/detail/83-transitional-

justice-and-the-european-convention-on-human-rights [last accessed 14 October 15 January 20198].
}

Formatted: Font: Not Italic

Field Code Changed

Formatted: Font: Not Italic

Formatted: Font: Not Italic

Formatted: Font: Not Italic

Formatted: Font: Not Italic

Formatted: Font: Not Italic

Formatted: Font: Not Italic

Formatted: Font: Italic 
consider its application in otherwise peaceful, consolidated democracies. ${ }^{7}$ While scholarship in this new expansionary area primarily considers the application of transitional justice to settler democracies such as Canada and Australia, its application has recently extended to historical institutional abuse elsewhere, such-as in Ireland and the United Kingdom. In this context, it is likely that the Strasbourg Court will be called again to address its historical application and the responsibilities of States towards historical abuse in the context of peaceful consolidated democracies. The widespread and systemic nature of historical institutional abuse revealed in existing reports in Council of Europe member states reveals the potential significant extension of liability were this expansion to gather pace. The child migration scheme in the United Kingdom and United States alone, where children were relocated from birth parents and home communities, involved 300,000 children between 1851 and 1970.8 To take the example of Ireland, commissions of inquiry revealed that sexual abuse was "endemic" in religious institutions throughout Ireland, with more than 1000 former pupils testifying with allegations physical and sexual abuse, ${ }^{9}$ with approximately 14,600 women engaged in forced labour in Magdalene laundries, and thousands of women allegedly subjected to illegal adoptions of their children in mother and baby homes. ${ }^{10}$

To date, Ireland, the United Kingdom, Austria, Belgium, the Netherlands, France and Germany have initiated investigations into historical abuse, primarily child sexual

\footnotetext{
${ }^{7}$ Henry, 'From Reconciliation to Transitional Justice: The Contours of Redress Politics in Established Democracies' (2015) 9 International Journal of Transitional Justice 199; Winter, 'Towards a Unified Theory of Transitional Justice' (2013) 7 International Journal of Transitional Justice 224.

${ }^{8}$ Lynch, Remembering Child Migration: Faith, Nation-Building, and the Wounds of Charity

(Bloomsbury Academic 2016).

9 'The Commission to Inquire into Child Abuse, Final Report- (Government Publications 2009),

$\frac{\text { available at: http://www.childabusecommission.ie/rpt/ [last accessed } 14 \text { October 2019]. }}{10}$ Maguire, 'Foreign Adoptions and the Evolution of Irish Adoption Policy, 1945-52' (2002) 36 Journal of Social History 387.
} 
abuse in the Roman Catholic church. ${ }^{11}$ Debate regarding potential expanded liability is unlikely to disappear, given the investigative trends in the jurisdictions mentioned and the attendant political pressure and disagreement regarding how victim-survivors should be redressed through law. However, any expansion of liability under the Convention engages the Court in a careful balancing of legal and political concerns, reflecting the margin of appreciation allowed to states parties and the Court's own perceived legitimacy in creating law as a supranational judicial institution. ${ }^{12}$ It is foreseeable that the Court is aware that consideration of historical abuse through the Convention may risk expanding the Court's workload or and its political legitimacy beyond its feasible limits.

To date, there is has been no exploration of the relationship between transitionalFormatted: Indent: First line: $0.63 \mathrm{~cm}$ justice, historical abuse outside the contexts of armed conflict or authoritarian rule, and the Convention. This article seeks to address that gap by considering the potential opportunities and obstacles for the use of the European Convention of Human Rights to address historical abuse in consolidated democracies outside of these contexts as part of transitional justice. Part 2 of this article will consider the expansionary trend in transitional justice and will address its application to Council of Europe member states, regarding historical institutional abuse. Part 3 will evaluate the development of ECtHR jurisprudence to date related to transitional justice. By understanding the Convention as a post-conflict legal instrument with an intention to protect and consolidate democratic societies, the role of the Court, as a supervisory body enabling societies to address past wrongdoing within a margin of appreciation, can be framed as a central element of the Court's purposes. Part 4 evaluates how the Court deals with the historical and inter-temporal application of the Convention. Part 5 explores the potential for the pilot judgment mechanism of the Court in responding to historical gross violations of human rights. Part 6 concludes by previewing the potential application of the Convention to historical abuse in the ongoing challenges to the legitimacy and political economy of the Court.

\footnotetext{
11 Gallen, 'Jesus Wept: The Roman Catholic Church, Child Sexual Abuse and Transitional Justice' (2016) 10 International Journal of Transitional Justice 332.

12 Madsen, 'The Challenging Authority of the European Court of Human Rights: From Cold War Legal Diplomacy to the Brighton Declaration and Backlash' (2016) 79 Law and Contemporary Problems 141.
} 


\section{TRANSITIONAL JUSTICE AND HISTORICAL ABUSE IN CONSOLIDATED DEMOCRACIES}

Since its emergence in the late 1980s and early 1990s, transitional justice has addressed how societies reckon with a legacy of gross violations of human rights in the context of a transition from armed conflict or authoritarian rule to stable, peaceful liberal democracy. ${ }^{13}$ As a body of scholarship and practice, transitional justice covers several discrete elements: truth seeking, accountability, reparation, institutional reform and reconciliation. ${ }^{14}$ Recent decades have seen a significant proliferation of transitional justice discourse and institutional practices from States and support from international institutions. The establishment and initial operation of the International Criminal Court confirms significant support from the international community for accountability for gross violations of human rights, albeit with considerable political and operational challenges in implementing this commitment. ${ }^{15}$ However, the effectiveness of transitional justice remains open to question, with suggestions that it remains "faith based rather than fact based". ${ }^{16}$ In addition, transitional justice remains subject to several justifiable critiques, such as mirroring the de-prioritisation of socioeconomic rights in mainstream human rights discourse. ${ }^{17}$ Other critiques suggest that transitional justice practice retains a significantly non-gendered approach to practice with a result that women are typically disadvantaged and de-prioritised in the provision of testimony, accountability and prosecution strategies, and access to effective remedies and redress. ${ }^{18}$ Nonetheless, transitional justice scholarship remains a highly self-reflective and self-critical area, in which such approaches seek to re-imagine and re-invigorate the concept and practice. ${ }^{19}$

\footnotetext{
${ }^{13}$ Arthur, 'How "Transitions" Reshaped Human Rights: A Conceptual History of Transitional Justice' (2009) 31 Human Rights Quarterly 321.

14 'United Nations Security Council. Report of the Secretary-General on the Rule of Law and

Transitional Justice in Conflict and Post-Conflict Societies (S/2004/616). August, 3 2004.' supra (n 5).

15 Gallen, 'The International Criminal Court: In the Interests of Transitional Justice?', in Lawther, Moffett and Jacobs (eds) Research Handbook on Transitional Justice (Edward Elgar Publishing 2017) 305-327.

16 Thoms, Ron and Paris, 'State-Level Effects of Transitional Justice: What Do We Know?' (2010) 4 International Journal of Transitional Justice 329.

17 Gready and Robins, 'From Transitional to Transformative Justice: A New Agenda for Practice' (2014) 8 International Journal of Transitional Justice 339.

${ }^{18}$ Campbell, 'The Gender of Transitional Justice: Law, Sexual Violence and the International Criminal

Tribunal for the Former Yugoslavia' (2007) 1 International Journal of Transitional Justice 411.

19 Turner, Violence, Law and the Impossibility of Transitional Justice (1st ed, Routledge 2017).
} 
Despite these perceived limitations, recent transitional justice scholarship has considered its potential for evaluating and guiding responses to other large scale or systematic human rights abuses beyond the context of armed conflict or authoritarian regimes. Lundy and McGovern argue that the paradigm of transitional justice "ignores the problem that human rights abuses may continue to take place in circumstances where, in theory at least, the norms of liberal democratic accountability prevail." 20 Winter argues that redress activity generally undertaken in established democratic states can be seen as a form of transitional justice because such measures aim to contribute to the de-legitimation of the state as a result of past historical injustices. ${ }^{21}$ Henry has argued that transitional justice may serve as providing a distinctive cohering or unifying function by bringing together discourses that exist on large scale human rights abuse across different jurisdictions, academic disciplines and fields of practice. ${ }^{22}$ This article suggests transitional justice should serve as an evaluative tool for assessing the response of peaceful consolidated democracies to large scale historical human rights abuses and for assessing the capacity and willingness of States and non-state actors to acknowledge the consequent need for fundamental transformation of the relations between institutions and the individuals and groups they claim to serve. ${ }^{23}$

An emergent practice of an expanded conception of transitional justice has followed, in addressing historical institutional abuse, involving entire classes of peoples, and particularly the historical marginalisation of women, especially women who became pregnant outside marriage, of the poor and of children, in consolidated democracies. Such harms are suggestive of a widespread and systematic practice that may be conceived of as human rights violations. These patterns of historical abuse can be framed as a "gross violation of human rights", which can be understood to include the core rights of human beings, notably the right to life and the right to physical and moral

\footnotetext{
20 Lundy and McGovern, 'Whose Justice? Rethinking Transitional Justice from the Bottom Up' (2008) 35 Journal of Law and Society 265.

${ }^{21}$ Winter, supra (n 7).

22 Henry, supra (n 7).

${ }^{23}$ Gallen, 'Jesus Wept' supra (n 11 ).
} 
integrity of the human person. ${ }^{24}$ The patterns of abuse referred to above in Ireland alone number in the tens of thousands. This expanded conception of transitional justice has involved several contexts. First, historical abuse has been addressed through a transitional justice lens in the context of settler democracies, especially in Canada and Australia. ${ }^{25}$ Second, investigations of the global Catholic Church by United Nations human rights treaty body mechanisms confirm the widespread and systemic nature of child sexual abuse in that institution. ${ }^{26}$ Third, specific Member States of the Council of Europe have begun to address their own legacy of historical abuse, which can be assessed holistically. In Ireland, four commissions of inquiry examined the child sexual abuse and how it was handled by church and state authorities in dioceses. ${ }^{27}$ Ireland's record in addressing historical abuse has been criticised before several United Nations bodies, including the CEDAW Committee, as recently as March 2017.28 In 2017, the Irish Minister for Children and Youth Affairs, Katherine Zappone, announced that she would initiate a 'transitional justice' approach to meet the needs of survivors of Mother and Baby Homes. ${ }^{29}$

A similar process is underway in the United Kingdom, albeit without explicit reference to transitional justice, where instead it may be employed as an evaluative tool to assess historical institutional abuse in a growing range of inquiries. Moynihan notes that "the last 10 years have seen multiple inquiries into historical deaths in Northern

${ }^{24}$ Van Boven, 'Victims' Rights to a Remedy and Reparation: The New United Nations Principles and Guidelines', in Ferstman, Goetz, Stephens (eds) Reparations for Victims of Genocide, War Crimes and Crimes against Humanity (Martinus Nijhoff Publishers) 34.

${ }^{25}$ Nagy, 'The Scope and Bounds of Transitional Justice and the Canadian Truth and Reconciliation Commission' (2013) 7 International Journal of Transitional Justice 52; Gallen and Gleeson, 'Unpaid Wages: The Experiences of Irish Magdalene Laundries and Indigenous Australians' (2018) 14 International Journal of Law in Context 43.

26 -United Nations Committee on the Rights of the Child, Concluding Observations on the Second Periodic Report of the Holy See ${ }_{2}\left(2014_{2}\right)$ CRC/C/VAT/CO/2'; Gallen, 'Jesus Wept', supra ( $n$

11).'United Nations Committee against Torture, Concluding oObservations on the Initial Report of the Holy See (2014) CAT/C/VAT/CO/1'.

27 'Report by Commission of Investigation into the Handling by Church and State Authorities of Allegations and Suspicions of Child Abuse against Clerics of the Catholic Archdiocese of Dublin' (Department of Justice, Equality and Law Reform 2009), available at

http://www.justice.ie/en/JELR/Pages/PB09000504 [last accessed 14 October 2019]; 'The Commission to Inquire into Child Abuse Final Report,'- supra (n 9); 'Report into the Catholic Diocese of Cloyne' (Department of Justice and Law Reform, 2011), available at

http://www.justice.ie/en/JELR/Cloyne Rpt.pdf/Files/Cloyne Rpt.pdf [last accessed 14 October 2019].

${ }^{28}$ United Nations Committee for the Elimination of Discrimination against Women, Concluding

Observations on the combined sixth and seventh periodic reports of Ireland CEDAW/C/IRL/CO/6-7

${ }^{29}$ Loughlin, 'Katherine Zappone: "We Will Find the Truth and Achieve Reconciliation " Irish

Examiner, 10 March 2017.

Formatted: Font: Italic

Formatted: Font: Italic 
Ireland in the 1970s, and there are numerous investigations ongoing into historical child sexual abuse dating back several decades." ${ }^{30}$ In the United Kingdom there have been several-numerous inquiries into child sexual abuse in State and Church institutions over several decades, with inquiries contemporary to the alleged abuse concerning specific institutions, ${ }^{31}$ and with subsequent investigations addressing historical institutional abuse. ${ }^{32}$ Similar investigative commissions into historical child sexual abuse have been established in Austria, Belgium and the Netherlands. ${ }^{33}$

It is in this context of ongoing innovation and expansion of transitional justice discourse and practice that the role of the European Convention on Human Rights and the Strasbourg Court will be evaluated. It will be argued that the Court's role as a guardian of democracy and human rights can be understood as informing the political and cultural changes involved with transitions relevant to historical abuse in peaceful consolidated democracies, as well as post-conflict and post-authoritarian states. Moreover, a transitional justice approach is necessary to effectively address nonsporadic and systemic violence and impunity, especially when perpetrated by powerful actors who have the means to elude accountability and maintain the legitimacy of their actions. Though the Court has offered an incremental approach to dealing to historical abuse, it remains highly possible that liability under the Convention exists for a variety of forms of historical abuse. A strictly individuated approach to human rights oversight, excluding transitional justice concerns, risks missing the bigger picture of and responsibility for human rights impunity.

\section{European Court_Human Right's JURISPRUDENCE ON TRANSITIONAL JUSTICE AND HISTORICAL ABUSE}

\footnotetext{
${ }^{30}$ Moynihan, 'Regulating the Past: The European Court of Human Rights' Approach to the Investigation of Historical Deaths under Article 2 ECHR' (โ2017)] British Yearbook of International Law 68-9.

${ }^{31}$ Corby, Doig and Roberts, 'Inquiries into Child Abuse' (1998) 20 Journal of Social Welfare and Family Law 377.

32 Shaw, Historical Abuse Systemic Review: Residential Schools and Children's Homes in Scotland 1950 to 1995. (Scottish Government 2007); 'Report of the Inquiry into Historical Institutional Abuse in Northern Ireland' (Northern Ireland Department of Finance 2017).

33 'Commission of Inquiry, Sexual Abuse of Minors in the Roman Catholic Church' (Uitgeverij Balans, Amsterdam 2011); 'Belgian Child Abuse Report Exposes Catholic Clergy' The Guardian ${ }_{1}(10$ September 2010); ' $€ 8 \mathrm{~m}$ for Austrian Abuse Victims', Agence France-Presse, ${ }_{2}$ (17 April 2012 ).
}

Formatted: Font: Italic

Formatted: Font: Italic 
Ní Aoláin has recently framed transition and transitional justice as a dominant motif for the emergent history and practice of the ECtHR, an instrument negotiated in a postWorld War II context, noting: "While the contemporary language of transitional justice [TJ] is not generally used to frame the post-Second World War transitions, one can with little effort trace the interface between the European Convention and the field of TJ." 34 Brems has noted that "since its adoption, ECHR case law related to transitional justice has included hundreds of judgments and decisions dealing with a wide range of issues, mainly compensation and restitution, but also prosecution, lustration, memory and truth." 35 Transitional justice offers a rich and diverse body of legal norms and practice regarding how to deal with a violent past involving such human rights violations, ${ }^{36}$ but can typically be disaggregated across four "pillars", which will form the basis in this article of assessing the contribution of the ECtHR: truth, accountability, reparation and institutional reform/vetting.

\section{A. Truth}

First, transitional justice theorises that truth about the past is a necessary but insufficient condition to redress past harms at individual and societal levels. ${ }^{37}$ To meaningfully address past violence and to determine appropriate measures of accountability and redress, it is necessary to have as clear and accurate an account of what has happened. In addition, especially for longer term historical forms of abuse, competing narratives and truths about the past can be effectively compared and analysed as nations wrestle with their national historical narratives. Sweeney writes that the '[t]he-right to truth has been comparatively slow to develop' in the Council of Europe system.'38 The ECtHR's approach has been to develop its conception of the right to the truth as linked to the state's obligation to investigate human rights violations, especially in contexts such as authoritarianism, armed conflict or counter-

\footnotetext{
${ }^{34}$ Ní Aoláin, supra $(\mathrm{n}$ 6 + at 17.

${ }^{35}$ Brems, 'Transitional Justice in the Case Law of the European Court of Human Rights' (2011) 5 International Journal of Transitional Justice 282.

${ }^{36}$ Ambos, 'The Legal Framework of Transitional Justice: A Systematic Study with a Special Focus on the Role of the ICC' in Ambos, Large and Wierda (eds), Building a Future on Peace and Justice (Springer Berlin Heidelberg-2009).

37 de Greiff, 'A Normative Conception of Transitional Justice' (2010) 50 Politorbis 19.

38 Sweeney, The European Court of Human Rights in the Post-Cold War Era: Universality in

Transition (1. publ, Routledge-(2013) p1 at 1.
} 
terrorism. ${ }^{39}$ In El-Masri, the ECtHR made its first explicit reference to the right to truth. Fabbrini notes that the case "confronts the emerging international human rights jurisprudence and seems to suggest that in cases of state atrocities public disclosure can be an important element of rehabilitation, satisfaction and guarantee of nonrepetition of the events." 40 Though explicitly mentioned, the right to truth remains controversial and divisive among the Strasbourg judiciary. In the separate opinion of Judges Tulkens, Spielmann, Sicilianos and Keller in El Masri, the right to the truth is described as a 'well-established reality', which is 'far from being either innovative or superfluous'. ${ }^{41}$ They rely on the Court's case law, the case law of the Inter-American Court of Human Rights, and statements at global human rights and at Council of Europe levels to support their views. ${ }^{42}$ In contrast, Judges Casadevall and Lopez Guerra conclude that judges have no place in introducing a right 'different from, or additional to' the provisions set out in the ECHR. ${ }^{43}$ Panepinto argues that by "discounting the development of the right to the truth about widespread violations as a concept that transcends individuality and affects society as a whole, they ignore the ECtHR' s own gradual contributions and the established position of the UN and IACHR jurisprudence." 44 She concludes that at present the Court's approach to the right to truth remains fragmented. ${ }^{45}$ Fabbrini agrees that the Grand Chamber's position reflects "an intermediate stand, failing to embrace fully a new paradigm of the right to the truth under Article 13 of the ECHR, but opening the possibility that the duty to investigate gross human rights abuses under Article 3 of the ECHR may be designed to remedy both individual and societal harms." 46 This emphasis is understandable from a long established international human rights treaty, which will seek to effectively

\footnotetext{
${ }^{39}$ Aslakhanova and $\theta$ Others v Russia . Apps Nos 2944/06 et al. and 8300/07, 50184/07, 332/08, 42509/10 Merits and Just Satisfaction, Judgment, 18 December 2012. Association 21 Décembre 1989 v Romania Applications Nos 33810/07 and 18817/08, JudgmentMerits and Just Satisfaction, 24 May 2011-; Mocanu and Oothers v Romania Applications. Nos 10865/09, 45886/07 and 32431/08, Merits and Just Satisfaction-Grand Chamber Judgment, 17 September 2014 [Grand Chamber]. ${ }^{40}$ Fabbrini, 'The European Court of Human Rights, Extraordinary Renditions and the Right to the Truth: Ensuring Accountability for Gross Human Rights Violations Committed in the Fight Against Terrorism' (2014) 14 Human Rights Law Review 85, at 102.

41 El-Masri v Macedonia, supra (n1) at Joint Concurring Opinion of Judges Tulkens, Spielmann, Sicilianos and Keller, at para 7.

42 ibid, paras 8-10.lbid., at paras 8-10.

43 ilbid at at Joint Concurring Opinion of Judges Casadevall and Lòpez Guerra.

44 Panepinto, 'The Right to the Truth in International Law: The Significance of Strasbourg's Contributions' (2017) 37 Legal Studies 739 at 750.

45 ibid.lbid.

${ }^{46}$ Fabbrini, supra $\left(n_{-}-40\right)$ at 102.
}

\begin{tabular}{|l|}
\hline Field Code Changed \\
\hline Formatted: Font: Not Italic \\
\hline Formatted: Font: Not Italic \\
\hline Formatted: Font: Not Italic \\
\hline Formatted: Font: Italic \\
\hline Field Code Changed \\
\hline Formatted: Font: Not Italic \\
\hline Formatted: Font: Not Italic \\
\hline Formatted: Font: Not Italic \\
\hline
\end{tabular}


balance its commitment to effective remedies for applicants against the subsidiary nature of rights protection and enforcement offered by the Convention.

However, the impact of the Court's division on the right to truth is arguably mitigated by the Court's clear and more developed jurisprudence on the related duty of State parties to investigate violations of human rights, especially regarding Articles 2 and 3 concerning the right to life and the right to be free from torture, inhuman or degrading treatment. While not explicitly framed as the right to truth or an element of transitional justice, this approach reflects the basis for the positive obligation to investigate gross violations of human rights established in the Inter-American Court of Human Rights 
jurisprudence as an element to the right to truth, ${ }^{47}$ and can readily be understood as part of the pillars of truth and accountability in a transitional justice paradigm. The right to life includes a procedural obligation to investigate deaths and disappearances and to identify and punish those responsible. In McCann $v$ United Kingdom, the Court held that a general legal prohibition of arbitrary killing by the agents of the State would be practically ineffective without a procedure to review the lawfulness of the use of lethal force by State authorities. ${ }^{48}$ An effective investigation must also consider 'all the surrounding circumstances including such matters as the planning and control of the actions under examination' 49 and have four elements: independence, promptness, transparency, and effectiveness. In McKerr v United Kingdom, the Court stated that to ensure effectiveness, 'the persons responsible for and carrying out' the investigation should be independent from those implicated in the events'.50 Secondly, the investigations must be prompt to maintain public confidence in adherence to the rule of law and in preventing any appearance of collusion in or tolerance of unlawful acts. Thirdly, the Court found that transparency is necessary, to practically secure accountability and that this should include allowing the victims' next-of-kin to be involved in the procedure 'to the extent necessary to safeguard his or her legitimate interests'. $\frac{51}{5}$ Finally, the Court has held that to be effective an investigation must be "capable of leading to a determination of whether the force used in such cases was or was not justified in the circumstances ... and to the identification and punishment of those responsible. This is not an obligation of result, but of means." 52 As a result, where an investigation does not result in a prosecution, this does not necessarily violate the state's obligation to investigate provided that the investigation was conducted in an effective manner. ${ }^{53}$ This approach has been subsequently affirmed repeatedly and extended to the lethal use of force by both State and private actors. ${ }^{54}$

\footnotetext{
${ }^{47}$ Ferrer Mac-Gregor, 'The Right to Truth as an Autonomous Right under the Inter-American Human Rights System' (2016) 9 Mexican Law Review 121.

48 McCann v United Kingdom (App No 18984/91); [1995] ECHR 18984/91, Merits and Just Satisfaction, 27 September 1995, [Grand Chamber], at para 161.

49 ibid at para 150.lbid at para 150.

50 McKerr v United Kingdom, Application no-No 28883/95, JudgmentMerits and Just Satisfaction, 4

May 2001 at para 112 .

51 lbid. at para 115.

52 lbid. at para 113.

53 ibid.lbid.

${ }^{54}$ Aliyeva and Aliyev v Azerbaijan Application no-No 35587/08, Judgment-Merits and Just

Satisfaction, 31 July 2014 at para 69; Kaya v Turkey, Application Nos (158/1996/777/978), JudgmentMerits and Just Satisfaction, 19 February 1998.
} 
Such requirements are not framed expressly as part of the right to truth, but instead are a measure of the procedural obligation to investigate under the Convention. Cases of widespread or systemic failure to investigate historical cases would present the Court with a challenge to consider whether the same individuated standard should apply.

A final element recently developed in Convention jurisprudence is the distinction Formatted: Space After: $0 \mathrm{pt}$ between individual forensic truths and a broader social interest in establishing the truth regarding historical violence. In El-Masri, the Grand Chamber stated that an adequate response and investigation is 'essential in maintaining public confidence in their adherence to the rule of law and in preventing any appearance of collusion in or 
tolerance of unlawful acts'. ${ }^{5}$ In Janowiec $v$ Russia, the ECtHR recognised both the public interest in a transparent investigation into the crimes of the previous totalitarian regime and the private interest of the victims' relatives in uncovering the circumstances of their death, but this can be contrasted against the significant cost that may attach to investigations of historical deaths. The ECtHR has drawn a distinction between a duty to investigate a death on the one hand, which concerns acts capable of leading to the identification and punishment of those responsible or to an award of compensation to the injured party, and other types of inquiries that may be carried out for other purposes, such as establishing a historical truth, on the other. ${ }^{56}$ In addition, the right to truth and investigations of historical abuse is multi-layered and generates obligations under other Articles of the Convention. The Court has held that it is an integral part of freedom of expression to seek historical truth. 57 The emerging right to access to information of public interest by members of the general public supports the existence of a collective dimension to the right to truth and is evidenced the Court's case law regarding Article 10 concerning NGOs seeking information of public interest. ${ }^{58}$

Brems notes that the ECtHR's jurisprudence suggests that such expression is an important public concern because it urges people 'to come to terms with the past' or because it 'might have repercussions on [a country's] future democratic development. ${ }^{59}$ Of particular import to historical abuse investigations, the Court has noted that when a significant amount of time has passed, restrictions on free debate seem even less justified. In addressing criticism of Switzerland's role during World War II, the Court held "the lapse of time makes it inappropriate to deal with such remarks, fifty years on, with the same severity as ten or twenty years before. That forms part of the efforts that every country must make to debate its own history openly

55 El-Masri v Macedonia, supra (n_1) at para 192, restated in the Joint Concurring Opinion of Judges Tulkens et al, para 6. See also Jelic v Croatia, Application No 57856/11, JudgmentMerits and Just Satisfaction, 12 June 2014, at para 94.

56 Janowiec and Others $v$ Russia ${ }_{2}$ supra $(\mathrm{n}$ 3) at paras 133; 214.

${ }_{57}$ Monnat v Switzerland, Application No 73604/01, JudgmentMerits and Just Satisfaction, 21 September 2006.

58 Youth Initiative for Human Rights v Serbia; Application No 48135/06, dudgment-Merits and Just Satisfaction, 25 June 2013; Magyar Helsinki Bizottság v Hungary Application No 18030/11 JudgmentMerits and Just Satisfaction, 8 November 2016 [Grand Chamber].

59 Karsai v Hungary, Application No 5380/07, JudgmentMerits and Just Satisfaction, 1 December 2009; Feldek v Slovakia, Application No 29032/95, JudgmentMerits and Just Satisfaction, 12 July 2001; Brems, supra (n 35), at 287.

\begin{tabular}{|l|}
\hline Formatted: Font: Not Italic \\
\hline Formatted: Font: Not Italic \\
\hline Formatted: Font: Not Italic \\
\hline Formatted: Font: Not Italic \\
\hline Formatted: Font: Not Italic \\
\hline Formatted: Font: Not Italic \\
\hline Formatted: Font: Fot Fot Italic Not Italic \\
\hline
\end{tabular}


and dispassionately." 60 As a result, while investigations and the pursuit of truth of longer term historical abuse may not always generate an obligation to investigate with a view towards potential individual accountability or punishment, the Convention continues to insist upon the desirability of enabling investigation and truth seeking of historical wrongdoing as part of the protection of freedom of expression and as being in the public interest of Member States. Finally, regarding the right to truth, the ECtHR has obliged states to provide effective individual access to personal files kept by public authorities that do not contain information that threatens national security. ${ }^{61}$ In Haralambie $v$. Romania, an individual had to wait more than six years to get access to personal files kept by the Romanian Securitate. The Court stated that the Romanian authorities had failed to fulfil their positive obligation to offer the applicant an effective and accessible procedure that would allow him to access his files within a reasonable amount of time. ${ }^{62}$ sisedescess to information and archives, public debate and discussion regarding historical wrongdoing form key elements of transitional justice, especially in the context of longer historical abuses where criminal accountability may be more difficult to establish.

\section{B. Accountability}

As noted earlier, the McKerr approach, by which states have an obligation of means not results, impacts the ECHR's approach to accountability for gross violations of human rights, as it means that even for unlawful killings, Article 2's procedural obligations will not necessarily be violated by the absence of criminal prosecutions. ${ }^{63}$ As a result, historical abuse inquiries into deaths in institutions may be required under the Convention, but need not operate with a goal of ultimate criminal prosecution. This seems particularly appropriate for the historical abuse context, where the possibility of obtaining custody of alleged perpetrators for events taking place decades ago becomes increasingly remote. In considering the obligation to prosecute, the Court

${ }^{60}$ Monnat v- Switzerland, supra (n 57), at para. 64.

${ }^{61}$ Gaskin v United KingdomK, Application No 10454/83, Judgment-Merits and Just Satisfaction 7 July 1989; Odièvre v France -Application No 42326/98, dudgmentMerits, 13 February 2003 [Grand

Chamber]; Leander v Sweden; Application No 9248/81, dudgment-Merits, 26 March 1987.

62 Haralambie v Romania, Application No 21737/03, dudgmentMerits and Just Satisfaction, 27 October 2009.

63 Mallinder, 'Investigations, Prosecutions and Amnesties Under Articles 2 \& 3 of the European

Convention on Human Rights' [2015] SSRN Electronic Journal 12 available at

http://www.ssrn.com/abstract=2668106 [last accessed 15-14 January October 20198].

Formatted: Font: Not Italic

Formatted: Font: Not Italic

Formatted: Font: Not Italic

Formatted: Font: Not Italic

Formatted: Font: Not Italic

Formatted: Font: Not Italic

Formatted: Font: Not Italic 
has also developed its view on amnesties for gross violations of human rights. In Marguš $v$ Croatia, the Court outlined a general view on the status and practice of amnesty laws. ${ }^{64}$ The ECtHR held that there was a growing tendency in international law to view the granting of amnesties in respect of grave breaches of human rights as unacceptable:

The possibility for a State to grant amnesty in respect of grave breaches of human rights may be circumscribed by treaties to which the State is a party. There are several international conventions that provide for a duty to prosecute crimes defined therein (see the Geneva Convention of 1949 for the Protection of Victims of Armed Conflicts and their Additional Protocols, in particular common Article 3 of the Geneva Conventions ... and the Convention Against Torture and Other Cruel, Inhuman, or Degrading Treatment or Punishment) ${ }^{65}$

The ECtHR acknowledged that the Inter-American Court of Human Rights had found that granting amnesties in respect of perpetrators of war crimes and crimes against humanity was incompatible with states' obligations under international law to investigate and prosecute war crimes. ${ }^{66}$ In Abdulsamat Yaman $v$ Turkey and Yesil and Sevim v Turkey, the Court ECtHR declared that amnesties, pardons or statutes of limitations should not apply to criminal cases involving torture and ill-treatment. ${ }^{67}$ Similarly in Ould Dah v France, it held that an amnesty is incompatible with states' duty to investigate and prosecute acts such as torture, which 'must hold true as regards war crimes' as well. ${ }^{68}$ Despite these decisions, Mallinder has suggested that ECtHR decisions continue to leave an space to enable amnesty in the context of peace processes or reconciliation between deeply divided communities, ${ }^{69}$ which seem less relevant to historical abuse contexts beyond armed conflict or authoritarian rule.

Article 2 also has a preventive function. In Osman $v$ United Kingdom, the Court noted that Article 2 requires states 'to take preventive operational measures to protect an

${ }^{64}$ Marguš v Croatia, Grand Chamber, Application no-No 4455/10, JudgmentMerits and Satisfaction, 27 May 2014 Grand Chamber].

65 ibid. lbid. at para 132

66 ibid.lbid., at para 138.

67 Abdulsamaet Yaman v Turkey, Judgment, Application no-No 32446/96, dudgmentMerits and Satisfaction, 2 November 2004, at para 55; Yesil and Sevim v Turkey, dudgment, Application no-No 34738/04, Merits and Satisfaction, 5 June 2007 at para 38.

68 Ould Dah v France, dudgment, Application na-No 13113/03, Admissibility. 17 March 2009.

${ }^{69}$ Mallinder, supra ( $\left.n-60\right)$; Mallinder, 'The End of Amnesty or Regional Overreach? Interpreting the Erosion of South Americas Amnesty Laws' (2016) 65 International and Comparative Law Quarterly 645.

\begin{tabular}{l} 
Formatted: Font: Not Italic \\
Formatted: Font: Not Italic \\
Formatted: Font: Not Italic \\
Formatted: Font: Not Italic \\
Formatted: Font: Not Italic \\
Formatted: Font: Not Italic \\
Formatted: Font: Not Italic \\
Formatted: Font: Not Italic \\
\hline
\end{tabular}


individual whose life is at risk from the criminal acts of another individual', but that that 'such an obligation must be interpreted in a way which does not impose an impossible or disproportionate burden on the authorities' and that a State would only be in breach of Article 2 when authorities knew or ought to have known at the time of the existence of a real and immediate risk to the life of an identified individual or individuals from the criminal acts of a third party and that they failed to take measures within the scope of their powers which, judged reasonably, might have been expected to avoid that risk. ${ }^{70}$ The retrospective application of the preventative obligation in Article 2 has not been considered to date in Convention jurisprudence, but the similar structure and development of the equivalent obligation in Article 3 jurisprudence, whose retrospective application has been considered in O'Keeffe, suggests it remains a possibility.

A similar procedural obligation exists under the prohibition of torture, inhuman or degrading treatment under Article 3 that relates to both truth and accountability from a transitional justice perspective. Notably for historical abuse cases, torture has also 
been extended to include rape and sexual violence. ${ }^{71}$ The McKerr approach of an effective investigation under Article 2 is replicated regarding Article 3. In Mikheyev $v$ Russia and in Association 21 Décembre $1989 v$ Romania, the Court found that investigations into serious allegations of ill treatment must be thorough, expedient, and independent and that the obligation to conduct them is one of means rather than endsresults. ${ }^{72}$ Under Article 3, States are not directly liable for acts of torture committed by private individuals, but are liable for failing to prevent torture by state agents or private individuals or where their legal framework does not provide adequate protection against torture or ill treatment. ${ }^{73}$ McGlynn concludes the Court's approach in considering whether treatment by non-state actors amounts to torture "is a clear implication that for a finding of torture, there does not have to be direct acts by a State agent." 74 Several cases extend the State obligation to prevent torture to private, including educational, settings. ${ }^{75}$ In $Z$ v. United Kingdom, the Court found that sexual abuse of children in the family home clearly contravenes Article 3 which obliged the State to provide effective protection of children and to take reasonable steps to prevent ill-treatment of which the authorities had or ought to have had knowledge. ${ }^{76}$

The role of Article 3 in regulating State prevention of abuse by private actors was clarified in O'Keeffe $v$ Ireland, where the applicant argued that Ireland failed to protect

71 Aydin v Turkey- Application Nos 57/1996/676/866, Merits and Satisfaction, 25 September 1997(1998) 25 EHRR 251; MC v Bulgaria Application No 39272/98, Merits and Satisfaction, 4 December 2003 [2003] ECHR 646; Ev the-United Kingdom, Application- No 33218/96, JudgmentMerits and Satisfaction, 26 November 2002; McGlynn, 'Rape, Torture and the European Convention on Human Rights' (2009) 58 International and Comparative Law Quarterly 565.

72 Mikheyev v Russia ,Application No 77617/01, dudgmentMerits and Satisfaction, 26th January 2006. Association 21 Décembre 1989 v Romania, App Application no 33810/07, Judgment, 24th May 2011.supra n 39.

${ }^{73}$ Kaya v Turkey, supra n 54App. No (158/1996/777/978), Judgment, 19 February 1998; D v United Kingdom App №no 30240/96, JudgmentMerits and Just Satisfaction, 2 May 1997; MC v Bulgaria ${ }_{2}$ App no 39272/98, Judgment, 4 December 2003.supra $n 71$.

74 McGlynn, supra (n $71+$ at 589.

${ }^{75}$ Costello-Roberts v United Kingdom 19 EHRR 112, Application no-No 13134/87, Merits and Just Satisfaction, 25 March 1993; A v the United Kingdom Application Nos 100/1997/884/1096, Judgment, Merits and Just Satisfaction, 23 September 1998, Reports 1998-VI.

${ }_{76} Z$ and Others $v$. the United Kingdom, Application noNo- 29392/95, Judgment-Merits and Just Satisfaction 10 May 2001 [Grand Chamber].

Formatted: Font: Not Italic

Formatted: Font: Not Italic

Formatted: Font: Not Italic

Formatted: Font: Not Italic

Formatted: Font: Not Italic

Formatted: Font: Not Italic

Formatted: Font: Not Italic

Formatted: Font: Not Italic

Formatted: Font: Not Italic

Formatted: Font: Not Italic 
her from sexual abuse and left her without an effective remedy. ${ }^{77}$ The Court affirmed that Article 3 creates a positive obligation for States to ensure protection against torture, or inhuman or degrading treatment, which was applicable in 1973. ${ }^{78}$ The Court considered that when relinquishing control of the education of children to non-State actors, Ireland should have been aware, given its inherent obligation to protect children, of potential risks to their safety if there was no appropriate framework of protection, including effective mechanisms for the detection and reporting of any illtreatment. ${ }^{79}$ While the O'Keeffe decision concerned a failure to prevent child sexual abuse in the context of primary education, the logic of State liability being created where the State delegates the provision of a public service to non-state actors and fails to maintain effective oversight or protection has the potential for application to other institutional contexts and other forms of abuse under Articles 2, 3 or perhaps Article 4 regarding slavery and enforced labour. The historical application of Article 3 present in O'Keeffe opens significant potential for considering other forms of historical abuse outside of armed conflict and authoritarian rule under the Convention.

The obligation to investigate and rights to truth and accountability regarding the whereabouts of missing people link the obligations under Article 3 in cases of enforced disappearances. These complex human rights violations can engage multiple forms of State liability. In Aslakhanova v Russia, the Court stated that a disappearance is 'a distinct phenomenon, characterised by an ongoing situation of uncertainty and unaccountability in which there is a lack of information or even a deliberate concealment and obfuscation of what has occurred', which 'over time, prolong[s] the

77 O'Keeffe v Ireland 35810/09, Judgmentsupra n 4., 28 January 2014.

Formatted: Font: Not Italic

78 ibid-lbid. at para 144

79 ibid lbid. at para 162; E. and Others v. the United Kingdom, supra n 71-App No. 33218/96, Judgment, 26 November 2002 a att para 99. 
torment of the victim's relatives'." 80 There can be a continuing violation of Article 3 found when a state persistently fails to account for missing persons, causing continuing suffering to their families. ${ }^{81}$ Though there have been several investigations into historical abuse in states parties, the Convention could conceivably be used where states parties refuse to address and investigate specific aspects of historical abuse. For instance, there have been no investigations into diocesan clerical sexual abuse in Northern Ireland, nor into alleged abuse in State run psychiatric hospitals in Ireland. In the face of national political fatigue regarding historical redress and limited national level legal avenues, the Convention obligations may provide a suitable mechanism to compel States to address their past.

\section{Reparations}

In addition to truth and accountability, transitional justice can typically involve reparations and redress to victim-survivors as the primary mechanism designed exclusively for the benefit of those affected by prior gross violations of human rights. Compensatory damages designed to achieve restitution in integrum often form part of a successful case at the ECtHR. However, the ECtHR approach to national level reparations has typically focused on whether such policies were established in a manner that was manifestly arbitrary or blatantly inconsistent with the fundamental principles of the ECHR, and not extended to creating an obligation on States to compensate for State violence generally. In Wos $v$ Poland, the Court considered whether a claim regarding eligibility for a national compensation scheme for the slavery and forced labour during World War II was admissible. The Court noted that: "under the Convention there is no general obligation for States to compensate wrongs inflicted in the past under the general cover of State authority. Consequently, substantive regulations which determine the eligibility criteria for any such compensation would, in principle, fall outside the Court's jurisdiction, unless the relevant criteria were established in a manner which was manifestly arbitrary or blatantly inconsistent with the fundamental principles of the Convention." 82 This

${ }^{80}$ Aslakhanova v Russia, supra fn_39t at paras $131_{2}=12 \underline{1-2} 2,121$.

81 Cyprus v Turkey; Application No 25781/94, Grand Chamber JügmentMerits and Just Satisfaction, 10 May 2001, [Grand Chamber] at para 154-7.

82 Wos v Poland, Application No 22860/02, Admissibility Judgment, 1 March 2005, at para 80; Brems, supra $(\mathrm{n} 35+290$.

Formatted: Font: Not Italic

Formatted: Font: Not Italic 
approach means that the Court's assessment and potential overturning of a national court judgment regarding national law will likely only occur in very exceptional cases.

Similarly, the extinction of individual claims as a result of participation in a general compensation scheme has been justified in the name of the public interest of legal certainty. In Poznanski v Germany, the applicant alleged violation of property rights under Article 1 Protocol 1 to the Convention. The case concerned compensation for the unjust enrichment of the corporation IG Farben through the forced labour of the applicant and others in concentration camps during World War II, which were excluded by the creation of a national legislative compensation scheme. The applicant alleged the scheme was adopted in the interests of industry and not a more general public interest and did not provide adequate compensation. The Court found there was a substantial public interest in establishing a legislative compensation scheme that would comprehensively address all forced labour claims and concluded that although it offered less compensation than theoretically might have been available in civil law, it did not upset the "fair balance" which has to be struck between the protection of property and the requirements of the general interest. ${ }^{83}$ Thus, aAny challenges to reparations schemes may be limited to evaluatinge whether the scheme is supervised by a judicial body with full jurisdiction and operating with fair procedures or whether arrangements for compensation strike a fair balance between individual interests and the general interests of the community. ${ }^{84}$

While the Court has considered the legitimacy of several administrative compensation schemes, further schemes have been operated in the context of historical abuse outside armed conflict or authoritarian rule. In Ireland alone, administrative redress schemes have operated for abuse suffered in residential schools, and Magdalene Laundries and for the forced application of the surgical procedure symphysiotomy. The Magdalene Laundries scheme has proven particularly unsatisfactory, with

83 Poznanski v Germany, Application No 25101/05, Admissibility 3 July 2002.

${ }^{84}$ Wos' v. Poland, Application no. 22860/02, JudgmentMerits and Just Satisfaction, 8 September 2006, at paras 92-112; Kiladze - $v$ Georgia, Application No 7975/06, JudgmentMerits and Just Satisfaction, 2 February 2010.
Formatted: Indent: First line: $1.27 \mathrm{~cm}$

Formatted: Font: Not Italic

Formatted: Font: Not Italic

Formatted: Font: Not Italic

Formatted: Font: Not Italic

Formatted: Font: Not Italic

Formatted: Font: Not Italic

Formatted: Font: Not Italic 
successful judicial review of its scope and application in $2017 .{ }^{85}$ In addition, reparations and redress in Ireland have avoided symbolic reparations, such as memorialisation or a museum. In particular, this remains the one outstanding recommendation of the report of the Commission to Investigate into Child Abuse. It remains open for the European Court to adopt a more robust conception of 'just satisfaction' (Article $41 \mathrm{ECHR}$ ) so as to include reparation other than in the form of compensation by following the Inter-American Court of Human Rights and including memorialisation and public ceremonies. ${ }^{86}$

\section{Institutional Reform/Vetting}

Institutional Reform/Vetting is a fourth transitional justice measure usually associated with the principle of guaranteeing non-repetition of human rights violations and usually linked with reform of the security sector. ${ }^{87}$ Vetting procedures can be evaluated under Article 6 regarding due process and Article 8 regarding the right to privacy. ${ }^{88}$ In $\bar{A}$ damsons $v$ Latvia, the Court established that any vetting procedure must be accessible and foreseeable and cannot exclusively serve the purpose of punishment or revenge. Any vetting law that restricts Convention rights must be sufficiently precise to determine the individual responsibility of the person identified and must contain procedural guarantees. Finally, national systems have been reminded that lustration laws are temporary in nature and the necessity of restricting individual rights diminishes over time. ${ }^{89}$ Though there have been inquiries into widespread child sexual abuse in the Roman Catholic Church in several states parties' jurisdictions, there has been no systemic review of the secretive application of Roman canon law, especially as regards the removal of priests and members of religious orders from their positions for abusive behaviour. It is questionable whether this application of canon law would pass the scrutiny of the Court.

\footnotetext{
${ }^{85}$ MKL and DC v Minister for Justice and Equality [2017] IEHC 389.

${ }^{86}$ Cassell, 'The Expanding Scope and Impact of Reparations Awarded by the Inter-American Court of Human Rights' (2016) 7 Revista do Instituto Brasileiro de Direitos Humanos 91, at 96.

${ }^{87}$ de Greiff, 'Vetting and Transitional Justice", Justice as Prevention: Vetting Public Employees in Transitional Societies (Social Science Research Council 2007).

${ }_{88}$ Matyjek v Poland, Application No 38184/03, JudgmentMerits and Just Satisfaction, 24 April 2007.

${ }^{89} \bar{A}$ damsons v Latvia, Judgment, Application no-No 3669/03, JudgmentMerits and Just Satisfaction, 24 June 2008.
}

\begin{tabular}{|l|}
\hline Formatted: Font: Not Italic \\
\hline Formatted: Font: Not Italic \\
\hline Formatted: Font: Not Italic \\
\hline Formatted: Font: Not Italic \\
\hline Formatted: Font: Not Italic \\
\hline Formatted: Font: Not Italic \\
\hline Formatted: Font: Not Italic \\
\hline Formatted: Font: Not Italic \\
\hline
\end{tabular}


Ní Aoláin emphasies that the Convention, as a post-war legal instrument, has sought to embed guarantees of non-repetition throughout the European human rights infrastructure. ${ }^{90}$ She suggests "it would be a mistake to focus only on the jurisprudence of the Court that explicitly contains a TJ motif as illustrative of the TJ 'work' of the Convention." ${ }^{1} 1$ Instead it is profitable to consider the range of legal and political ways in which the Convention can be used by national actors to influence transitions and the cessation of conflict. ${ }^{92}$ Brems reminds us that while the obligation to investigate individual allegations of violations of Articles 2 and 3 persists across states parties, the obligation to investigate historical abuse at a societal level offers them some discretion in how they interpret and structure the manner in which they deal with their past. ${ }^{93}$ Such an approach reflects not only the subsidiary nature of the Convention, but also the view in transitional justice scholarship and practice that there is no one size fits all approach to addressing a legacy of gross violations of human rights, but instead the appropriate approach should be guided by local context and through the empowerment of local owners, especially victim-survivors. ${ }^{94}$ In turn, it may be profitable to consider how the Convention is employed by actors within consolidated democracies who remain subject to these obligations, but where the concept of "transition" is less explicit than in the contexts of post-conflict or post-authoritarian states. The Court's above jurisprudence affirms the broad supervisory role of the Convention in partially structuring how states parties address their historical wrongdoing. However, a likely challenge or objection to the application of transitional justice style obligations to contexts of historical abuse is that it involves either a retrospective or retroactive application of the Convention to a prior historical period or that it involves an illegitimate extension of the Convention's jurisdiction to a prior historical period.

\section{THE APPLICATION OF THE CONVENTION TO HISTORICAL ABUSE IN PEACEFUL CONSOLIDATED DEMOCRACIES}

\section{A. Continuing Violations of the Convention}

\footnotetext{
90 Ní Aoláin, supra (n_-6) at 6.

91 ibid 18.lbid. at 18.

92 Ibid.

93 Brems, supra $(\mathrm{n} 3-35)$ at $287-8$.

${ }^{94}$ Vinck and Pham, 'Ownership and Participation in Transitional Justice Mechanisms: A Sustainable Human Development Perspective from Eastern DRC' (2008) 2 International Journal of Transitional Justice 398 .
} 
The application of the European Convention regarding transitional justice to issues of historical abuse raises inevitable questions of whether and how today's standards are applied to events that took place in the past, in some instances, multiple generations ago. Moynihan highlights some of these issues:

\begin{abstract}
"On the one hand, the universality of human rights demands that in principle at least, justice should be done regardless of how far back in time the death took place, particularly in cases where the deaths concerned amount to serious crimes of international law. At the same time, should states be held to account for acts that occurred before they even agreed to be bound by the obligations in the Convention? What about the principle of non-retroactivity, under which a treaty does not bind a party in relation to acts or facts which preceded the date of entry into force of the treaty for the party concerned? The investigation of deaths occurring before a state became a party to the Convention also gives rise to practical considerations. Claims into the distant past will be unmanageable if there are no longer victims, evidence or witnesses available." ${ }^{95}$
\end{abstract}

General rules of treaty interpretation suggest that a treaty should be interpreted as understood at the time of its conclusion. ${ }^{96}$ The Strasbourg courtCourt has applied this principle to deny claims relating to periods when the ECHR was not in force for the State concerned. 97

One of the key challenges regarding twentieth century historical abuse in consolidated democracies is that it may relate to time periods before the creation or application of the Convention or relate to a period of time where different social and legal standards may be relevantapplied. Innovative solutions to some of these procedural challenges have been found through the articulation of the doctrine of 'continuing violation', where the original human rights violation results in ongoing loss of use, enjoyment and

\footnotetext{
95 Moynihan supra (n 30 ) at 70.

${ }^{96}$ Elias, 'The Doctrine of Intertemporal Law', 74 (1980) AJlL American Journal of International Law (1980) 285; Fitzmaurice, 'The Law and Procedure of the International Court of Justice: General Principles and Sources of Law', 30 (1953) BYILBritish Yearbook of International Law 1.

97 Varnava and Others v. Turkey Application nosNos. 16064/90, 16065/90, 16066/90, 16068/90, 16069/90, 16070, 16071/90, 16072/90 and 16073/90, Merits and Just Satisfaction-Grand Chamber Judgment, 18 September 2009_Grand Chamber], at para 130.
} 
access resulting from the denial of rights. ${ }^{98}$ Pauwelyn defines a continuing violation as: "the breach of an international obligation by an act of a subject of international law extending in time and causing a duration or continuance in time of that breach." 99 The ECtHR and formerly the European Commission of Human Rights have both long recognised the existence of continuing violations as an exception to the strict application of the temporal jurisdiction of the Convention. 100 The European Court has acknowledged continuing situations in the two categories: first, single situations starting at a single point in time and continuing uninterrupted until the situation ceases. ${ }^{101}$ A second category are composite acts, defined as "a series of actions or omissions defined in aggregate as wrongful occurs when the action or omission occurs which, taken with the other actions or omissions, is sufficient to constitute the wrongful act." 102 Examples include an accumulation of 65 judgments against Italy regarding the reasonable time of proceedings before civil courts. ${ }^{103}$ To establish the existence of a continuing situation, an applicant will need to prove a sufficient relation between the different parts of a situation or the various acts that are to be taken into account. For composite or complex situations, one will need to demonstrate "events, taken together, form a pattern of conduct. Where intentional acts are concerned, the relation between the acts will usually follow from a common intention." 104 In cases of continuing violations such as enforced disappearances the Court has noted that "applicants cannot wait indefinitely before coming to Strasbourg. They must make proof of a certain amount of diligence and initiative and introduce their complaints without undue delay."105

${ }^{98}$ Loizidou v Turkey, Judgment, Application no-No 153118/89, Preliminary Objections Judgment, 23 March 1995 [Grand Chamber].

${ }_{99}$ Pauwelyn, 'The Concept of a "Continuing Violation" of an International Obligation: Selected Problems' (1996) 66 British Yearbook of International Law 415.

${ }_{100}$ Van Pachtenbeke and Haeck, 'From De Becker to Varnava: The State of Continuing Situations in the Strasbourg Case Law' (2010) 1 European Human Rights Law Review 47.

101 Jecius v Lithuania-Application No 34578/97, Merits and Just Satisfaction, 31 July 2000(2000) 35 EHRR 16; Lyubimenko v Russia Application No 6270/06, Judgment-Merits and Just Satisfaction. 19 March 2009.

102 'Draft Articles on Responsibility of States for Internationally Wrongful Acts, with Commentaries' (2001) UN/A/RES/56/83. Article 15.

${ }^{103}$ Wolf, 'Trial within a Reasonable Time: The Recent Reforms of the Italian Justice System in

Response to the Conflict with Article 6(1) of the ECHR' (2003) 9 European Public Law 189.

104 Van Pachtenbeke and Haeck, supra (n_-10099) at 54.

105 Varnava $v$ Turkey, supra $(n, 97)$ at para 160.

Formatted: Font: Not Italic

Formatted: Font: Not Italic
Formatted: Font: Not Italic

Formatted: Font: Not Italic

Formatted: Font: Not Italic

Formatted: Font: Not Italic

Formatted: Font: Not Italic

Formatted: Font: Not Italic 


\section{B. The "Critical Date" as a Limitation to the Application of the Convention}

However, there are limits to the capacity of individuals to invoke the "continued violation" mechanism. The Court has until recently consistently held that the provisions of the Convention do not bind a contracting party in relation to acts, facts or situations which occurred before the "critical" date when the state in question became a party to the Convention. ${ }^{106}$ In this regard it aligns itself with the approach in public international law more generally concerning the non-retrospective or retroactive application of treaties, ${ }^{107}$ and reflects an intention of this approach to enable legal certainty and foreseeability for States. However, in 2009, in Šilih $v$ Slovenia, the applicants claimed there had been an inefficient investigation into the death of their son, which had occurred a year before Slovenia ratified the Convention. The Grand Chamber held that the procedural duty to carry out an effective investigation under article Article 2 had evolved into a separate and autonomous duty detachable from the substantive aspect of article-Article 2 and was capable of binding the state even when the death took place before the critical date. ${ }^{108}$ The Court noted that, beyond Article 2, the ECtHR had previously extended its temporal jurisdiction to take into account underlying facts and acts which occurred prior to the critical date, "where they are causally connected with subsequent facts that form the sole basis of the complaint and of the court's examination."109 Several dissenting judgments aligned with academic criticism suggesting the approach taken was equivalent to the retrospective application of the Convention. ${ }^{110}$ In Šilih, the ECtHR had relied on the case law of the IACtHR and the UN's Human Rights Committee, particularly their continuing violation jurisprudence, to support detachment of the procedural obligation from the underlying act. ${ }^{111}$ Nonetheless, perhaps mindful of its considerable backlog in workload and

\footnotetext{
${ }^{106}$ Moynihan, supra (n 30) $\underline{\text { at } 72-3 .}$

${ }^{107}$ Article 28, Vienna Convention on the Law of Treaties, 1155 U.N.T.S. 331, 8 I.L.M. 679, entered into force Jan. 27, 1980; Greece v United Kingdom, 1 July 1952, ICJ Reports (1952) 40.

108 Šilih v Slovenia Application no-No 71463/01-, Merits and Just Satisfaction Grand Chamber Judgment,- 9 April 2009 [Grand Chamber].

109 libid. at paras 141-7.

110 Bjorge, 'Right for the Wrong Reasons: Silih v Slovenia and Jurisdiction Ratione Temporis in the European Court of Human Rights' (2013) 83 British Yearbook of International Law 115.

111 Case of the Serrano-Cruz Sisters v El Salvador (Preliminary Objections) IACtHR Series C No-118

(23 November 2004); Case of the Moiwana Community v Suriname (Preliminary Objections, Merits, Reparations and Costs) IACtHR Series C No. 124. Inter-American Court of Human Rights (15 June
}

\begin{tabular}{|l|}
\hline Formatted: Font: Not Italic \\
\hline Formatted: Font: Not Italic \\
\hline Formatted: Font: Not Italic \\
\hline Formatted: Font: Not Italic \\
\hline Formatted: Font: Not Italic \\
\hline Formatted: Font: Not Italic \\
\hline Formatted: Font: Not Italic \\
\hline Formatted: Font: Not Italic \\
\hline Formatted: Font: Not Italic \\
\hline Formatted: Font: Not Italic \\
\hline
\end{tabular}


challenges to its efficiency and perceived legitimacy, the Court offered limiting criteria for its new approach:

First, it is clear that where the death occurred before the critical date, only procedural acts and/or omissions occurring after that date can fall within the Court's temporal jurisdiction. Second, there must be a genuine connection between the death and the entry into force of the Convention in respect of the respondent State... Thus a significant proportion of the procedural steps required by this provision. . . will have been or ought to have been carried out after the critical date. However the Court would not exclude that in certain circumstances the connection could also be based on the need to ensure that the guarantees and the underlying values of the Convention are protected in a real and effective manner. ${ }^{112}$

Schabas criticised these criteria as overly vague and challenging in application, particularly the exception regarding the application of unspecified "underlying values of the Convention". ${ }^{113}$ The Court soon took the opportunity to clarify their application. In 2013, in Janowiec $v$ Russiain 2013, the deaths concerned took place not only prior to the critical date for Russia (1998), but also prior to the adoption of the Convention (1950). The applicants argued that Russia was in breach of a procedural duty under article 2 to investigate the massacre by Soviet troops of nearly 22,000 Polish soldiers and citizens in 1940, potentially understood as a war crime. ${ }^{114}$ The Grand Chamber held that the 'genuine connection test' in Silih has two limbs. First, the lapse of time between the death and the entry into force of the Convention for the state concerned must be no more than 10 years. ${ }^{115}$ Some have criticised this approach as unnecessarily arbitrary, ${ }^{116}$ especially as a year before Janowiec the ECtHR held that the genuine connection test was met where the death occurred 13 years before the critical date. ${ }^{117}$

Second, a major part of the investigation must have been carried out, or ought

2005); UNHRC, Sandra Lovelace $v$ Canada, Communication no-(24/1977), Views, UN Doc CCPR/C/13/D/24/1977.CCPR/Ct.

112 Šilih $v$ Slovenia, supra (n 108) at paras 162-3.

113 Schabas, 'Do the "Underlying Values" of the European Convention on Human Rights Begin in 1950?' (\{2014)\} Polish Yearbook of International Law 247.

114 Janowiec and Others $v$ Russia, supra, $(n, 3)$.

115 ibid at para 40 .lbid. at para 40.

${ }^{116}$ Citroni, 'Janowiec and Others v. Russia: A Long History of Justice Delayed Turned into a

Permanent Case of Justice Denied' (\{2014)\} Polish Yearbook of International Law 279.

117 Mladenovic v v Serbia Application no-No 1099/08 Judgment-Merits and Just Satisfaction, 22 May 2012.

Formatted: Font: Not Italic

Formatted: Font: Not Italic

Formatted: Font: Not Italic

Formatted: Font: Not Italic

Formatted: Font: Not Italic

Formatted: Font: Not Italic

Formatted: Font: Not Italic

Formatted: Font: Not Italic

Formatted: Font: Not Italic

Formatted: Font: Not Italic

Formatted: Font: Not Italic

Formatted: Font: Not Italic 
to have been carried out, after the critical date. The Grand Chamber explained that the first limb was the more crucial of the two $;{ }^{118}$ and is likely to remain a challenging task. The most challenging cases are those of omission, where a State fails to investigate deaths or carries out an ineffective investigation. The Court has stated that the obligation to investigate is not unceasing and persists over time, ${ }^{119}$ but instead "only binds the state throughout the period in which the authorities can reasonably be expected to take measures with an aim to elucidate the circumstances of the death and establish responsibility for it."120 For those-historical cases, the Court clarified in Janowiec that a duty to investigate_after the 'critical date' may be triggered 'when a plausible, credible allegation, piece of evidence or item of information comes to light which is relevant to the identification and eventual prosecution or punishment of those responsible' and which is 'sufficiently weighty and compelling to warrant a new round of proceedings". ${ }^{121}$ This approach, a "new element test", reflects the approach in Brecknell $v$ United Kingdom, which concerned an article 2 investigation into deaths that occurred after the critical date. ${ }^{122}$ Moynihan notes that "it is activity after the critical date, whether ongoing proceedings (as in Silih) or new information emerging (as in Janowiec), that serves as the proper trigger for the newly detached procedural duty to be animated, rather than the death itself." 123

In the context of historical abuse, national inquiries in recent decades seem a paradigmatic "new element", especially as several investigations into child sex abuse have resulted in the identification and prosecution of those responsible in a manner not possible prior to the inquiry. Prior to such investigations, victims of historical abuse may not have pursued litigation under these causes of action in the reasonable belief that the conduct under which they were abused was legal and endorsed by the State. For instance in Ireland, some of the women who were detained in the Magdalene

118 Janowiec and Others $v$ Russia ${ }_{1}$ supra (n 3 t at para 40.

119 ibid at para 140.

120 Šilih v Slovenia ${ }_{1}$ supra $\left(n_{1} 108\right)$ at para 157.

121 Janowiec and Others $v$ Russia ${ }_{1}$ supra $(n \underline{3} 3)$ at para 144.

122 Brecknell v United Kingdom Application no-No 32457/04 Judgment-Merits and Just Satisfaction, 27 November 2007.

${ }^{123}$ Moynihan, supra $(\mathrm{n} 30)$ at 82. 
laundries had been placed in the laundries subject to a court order or State action. ${ }^{124}$ It may be unrealistic and unreasonable to expect such individuals to engage in litigation, especially to a Convention level, in the absence of any support for the view that their alleged abuse constitutes illegal behaviour. Suggesting that victim-survivors of historical abuse should have pursued legal action contemporary to their abuse ignores both the psychological and traumatic effects of intense physical or sexual abuse, but also creates an artificially receptive historical context. Investigations into abuse in a variety of historical contexts demonstrate the unwillingness or inability of State and church authorities to respond effectively to such complaints, or a lack of belief in the accusations of victim-survivors against socially respected authority figures. ${ }^{125}$ Broader historical abuse inquiries that address individual records and archives may also generate a new "plausible, credible allegation, piece of evidence or item of information". By virtue of engaging in investigations into historical abuse through national level mechanisms states parties to the Convention have arguably extended the application of the Convention jurisdiction to address the circumstances and temporal mandates of those historical abuse inquiries.

\section{The Extension of Convention Values into History: A Limited Approach}

Finally in Janowiec the Grand Chamber held that, in exceptional cases, the procedural obligation in Article 2 applies even though the two requirements of the 'genuine connection' test explained above are not met. This is so where the alleged offences are contrary to the 'underlying values' or foundations of the Convention. The Grand Chamber stated that Chamber noted that references to the underlying values of the Gonvention required that: "the required connection may be found to exist if the triggering event was of a larger dimension than an ordinary criminal offence and amounted to the negation of the very foundations of the Convention. This would be

\footnotetext{
${ }^{124}$ Dail Eireann Parliamentary Debates, Written Answer from Dermot Ahern, TD, Minister for Justice, Equality \& Law Reform to Ruairi Quinn, TD (19 January 2010); National Archives of Ireland, Central Criminal Court Trial Record Books (1926-1964), cited by Smith, Ireland's Magdalen Laundries and the Nation's Architecture of Containment (Manchester University Press, 2008), 63; Irish Human Rights Commission, Assessment of the human rights issues arising in relation to the treatment of women and girls in Magdalen laundries (2010).

${ }_{125}$ Report of Tthe Commission to Inquire into Child Abuse, Executive Summary Final Report, supra n 9 available at http://www.childabusecommission.ie/rpt/ExecSummary.php; McGee, Garavan, de Barra, Byrne, Conroy. The SAVI Report: sexual abuse and violence in Ireland: (Dublin: Dublin Rape Crisis Centre; 2002).
}

Formatted: Superscript

Formatted: Superscript

Formatted: Superscript

Formatted: Superscript

Formatted: Font: Italic

Formatted: Font: Italic 
the case with serious crimes under international law, such as war crimes, genocide or crimes against humanity." 126 Moynihan suggests that the Convention values test appears to be aimed at avoiding a legal vacuum in human rights protection by providing a basis for the ECtHR to assert jurisdiction over claims for investigations into events 'of a larger dimension than an ordinary criminal offence' that precede the critical date for the state concerned. ${ }^{127}$ This approach reflects a commitment to countering impunity for historical offences, particularly genocide, war crimes and crimes against humanity, that is one of the central animating forces behind international criminal law and transitional justice. To date, Convention values have been employed to justify the protection of democratic institutions, the management of free speech in the context of hate speech and Holocaust denial, and religious expression in the context of employment. ${ }^{128}$ The references to Convention values in Šilih and Janowiec continue this trend but shift its application from a negative disabling on reliance on the Convention contrary to its values, to a justification for imposing obligations on States. ${ }^{129}$ Some dissenting opinions suggest this will involve a complex case by case assessment of Convention values and their interaction with the temporal jurisdiction of the Court, ${ }^{130}$ but, with respect, these processes already exist separately in the Court's interpretation of the Convention and its own role.

Second, the doctrine of continuing violations demonstrates the potential for prior, indeed historical human rights abuses, to have ongoing consequences for victim-survivors in the present day. The violations involved in an enforced disappearance demonstrate that the ongoing uncertainty and suffering caused by a lack of knowledge regarding the whereabouts and status of a loved one can cause an additional distinctive form of harm to family members searching for such loved ones under Article 3 of the Convention. It may be that not all historical forms of human rights abuse retain sufficient links to individual applicants today to warrant the extension of Convention jurisdiction. However, it would seem most prudent to enable the Court to make individuated assessments of this, rather than arbitrarily deny a small cohort of

\footnotetext{
126 Janowiec and Others $v$ Russia supra $(n+3)$ at para 150.

127 Moynihan, supra (n 30) at 86.

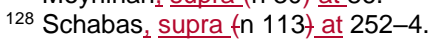

129 Moynihan, supra (n 30 ) at 87.

130 Šilih v Slovenia ${ }_{1}$ supra $\left(n_{-} 110\right)$ Concurring Opinion of Judges Zagrebelsky, Rozakis, Cabral
} Barreto, Spielmann and Sajo. 
elderly applicants access to Convention protection without considering their relationship to the harms alleged.

Further clarification is nonetheless likely warranted from the Court about the temporal scope of the Convention under these Janowiec criteria. Differing views of the judges not only on the issue of the critical date, but also on the type of new evidence required to revive the procedural duty under article 2 , evidence show the need for further guidance from the ECtHR. ${ }^{131}$ However, in principle it is possible on this approach to extend the Convention jurisdiction to historical abuse pre-dating critical

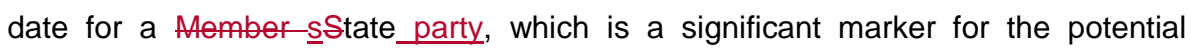
application of transitional justice to historical abuse in consolidated democracies. In Tuna $v$ Turkey and Yatsenko $v$ Ukraine, the Court has extended these criteria regarding the procedural obligation to investigate-cruel, inhuman or degrading treatment under article 3. ${ }^{132}$ Moynihan speculates that the Convention values test may also found claims arising both armed conflict or historical child sexual abuse, where there is fresh evidence to suggest that the alleged events took place between 1950 and the critical date for the state concerned. ${ }^{133}$

However, in Janowiec, the Grand Chamber went on to hold that, despite the grave nature of the crimes concerned, the underlying Convention values test "cannot be applied to events which occurred prior to the adoption of the Convention, on 4 November 1950, for it was only then that the Convention began its existence as an international human rights treaty." Janowiec thus restricted further the circumstances in which a claim would fall within the Court's jurisdiction. The dissenting opinions noted the irony that the exception developed to enable jurisdiction over significant historical human rights violations was not applied to the Katyn massacre in this instance. ${ }^{134}$ As

131 Moynihan, supra (n $30+$ at 97

132 Tuna v Turkey Application no-No 22339/03, dudgment-Merits and Just Satisfaction, 19 January 2010; Yatsenko v Ukraine Application Nao 75345/01, JudgmentMerits and Just Satisfaction, 16 February 2012.

${ }^{133}$ Moynihan, supra (n 30$)$ at 89.

134 Janowiec and Others $v$ Russia supra (n 3) at Joint Partly Dissenting Opinion of Judges Spielmann, Villiger and Nußberger.

Formatted: Font: Not Italic

Formatted: Font: Not Italic

Formatted: Font: Not Italic

Formatted: Font: Not Italic

Formatted: Font: Not Italic

Formatted: Font: Not Italic

Formatted: Font: Not Italic

Formatted: Font: Not Italic 
with the 10-year rule in the 'genuine connection test', drawing a line in history risks the appearance of arbitrariness, particularly in a human rights context. ${ }^{135}$

The Court's approach to the historical application of the Convention continues to develop in an incremental fashion, suggesting its potential further application to nonconflict historical abuse. In O'Keeffe $v$ Ireland, the Court agreed that the abuse suffered by the applicant in 1973 was contrary to Article 3, concluding that since 1958 the rights of children were identified as in need of special attention. ${ }^{136}$ However, Judge Ziemele noted that the majority's approach did not align well with accepted approaches to the evolution of legal standards in international law, drawing on both international human rights instruments and relevant case law subsequent to $1973 .{ }^{137}$ The joint partly dissenting opinion of Judges Zupančič, Gyulumyan, Kalaydjieva, De Gaetano and Woityczek concluded that there was no relevant case law in 1973 to support the majority's view of the positive obligation to protect, and prevent the illtreatment of, children at school as requiring "an appropriate framework of regulations encouraging complaints". ${ }^{138}$ The judges noted: "[i]t is Kafkaesque to blame the Irish authorities for not complying at the time with requirements and standards developed gradually by the case-law of the Court only in subsequent decades."139 In contrast, in Varnava and Others $v$. Turkey, the Court observed that interpretation of the Convention obligations cannot be equated to a retroactive imposition of liability and concluded its case-law is a means of clarifying pre-existing texts to which the principle of non-retroactivity does not apply in the same manner as to legislative enactments. ${ }^{140}$

While the Court remains unlikely to articulate a comprehensive interpretive methodology, some broader guidance is welcome to avoid suggestions of ad-hoc and

\footnotetext{
135 Schabas $_{1}$ supra fn 113t at 254-5.

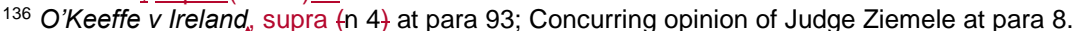

137 O'Keeffe v Ireland supra (n_4) at para 147; Joint partly dissenting opinion of Judges Zupančič,

Gyulumyan, Kalaydjieva, De Gaetano and Wojtyczek at para 8.

138 O'Keeffe v Ireland, supra n 4 Joint partly dissenting opinion of Judges Zupančič, Gyulumyan, Kalaydjieva, De Gaetano and Wojtyczek at para 8.

139 ibid lbid. at para 9.

140 Varnava and Others v. Turkey supra (n_97), para 140.
}

Formatted: Font: Not Italic
Formatted: Font: Not Italic
Formatted: Font: Not Italic
Formatted: Font: Not Italic


ideological judicial activism. ${ }^{141}$ It may be possible that states parties would be more likely to endorse the Convention's application to historical abuse if they could predict and define its parameters and take steps in national laws and policies to comply with Convention standards in their ongoing redress for historical abuse. As a result of the decisions in El-Masri, Janowiec, and O'Keeffe, the Court has raised the spectre of an apparent clash of values. The pursuit of truth, including the exploration of historical truth not necessarily leading to individual accountability, can be contrasted with the Court's desire to pragmatically limit the critical date of application of the Convention for states parties and the methodology employed in ascertaining the historical application of Convention standards. The apparent tension between these concerns is unlikely to be comprehensively clarified given the Court's preferred incrementalism and pragmatic awareness of the political economy of its own perceived legitimacy. It would be regrettable if different cohorts of victims of historical abuse were treated differently depending on whether the Court prioritised the right to truth jurisprudence or methodology in O'Keeffe in one case and privileged the concerns in Janowiec in another. In O'Keeffe, Judge Ziemele correctly concluded "it is indeed high time that the Court acknowledged the issue of time and took care to explain clearly its methodology as regards the application of the Convention over time." 142 One manner in which this may be achieved is in the Court articulating a coherent link between its temporal jurisdiction, methodology and the principle of subsidiarity.

\section{Convention Values and the Need for Subsidiarity}

The Court is the inevitable custodian and adjudicator on Convention values, and its express consideration of its own institutional role in shaping the Convention's temporal mandate seems a natural extension of the values that cohere rights and obligations within the Convention. In developing the substantive protection of rights in the Convention as a post-war instrument, the Court has sought to protect democracies through the promotion of human rights responsibilities for states. Ni Aolain has argued that transitional justice values thus are imbued through the Convention and its jurisprudence. It follows that the protection of democracy and guarantee of nonrepetition of human rights violations could extend to the emergence practice of

${ }^{141} \mathrm{Cf}$ Mowbray, "The Creativity of the European Court of Human Rights" (2005) 5(1) Human Rights Law Review 57-79, at 71.

${ }_{142}$ O'Keeffe $v$ Ireland supra $(\mathrm{n}$-4) Concurring opinion of Judge Ziemele at para 1. 
transitional justice in consolidated democracies. Democracy, like peace, is a status societies and courts must be ever vigilant to maintain.

In contrast, Schabas is critical of the potential for the underlying values element of the Convention's temporal jurisdiction to risk creating open ended State obligations to investigate any relevant historical deaths and risked creating an obligation for claims regarding the Spanish Civil War, Armenian genocide, Irish famine or colonial-era human rights abuses. ${ }^{143}$ Similarly judicial opposition to an expansive approach is evident in Janowiec where Judges Kovler and Yudkivska stated 'the Convention system and jus cogens rules in the global context should effectively serve the modern world rather than history." 144 Schabas notes the potential for a forward looking orientation to the Convention:

"The European Convention on Human Rights could well have been designed to deal with previous violations of human rights. The only reason this was excluded is because of the reluctance of the States that drafted the Convention to take responsibility for past abuses. In any case, the procedural obligation relates to the conduct of investigations after entry into force of the Convention, not before, and in this sense it is not retroactive even if it is sparked by events that are themselves outside the Court's temporal jurisdiction." 145

A further concern is that while it can be argued that transitional justice values permeate the Convention, other Convention values may point towards a reduced role for the Court in extending its jurisdiction regarding historical abuse and transitional justice. In particular, the interaction of subsidiarity and transitional justice needs to be considered further.

Carozza defined subsidiarity as "the principle that each social and political group should help smaller or more local ones accomplish their respective ends without, however, arrogating those tasks to itself." 146 The requirement for applicants to the Court to exhaust domestic remedies and the Court's margin of appreciation doctrine reflect the "normative subsidiarity" associated with the principle that states

143 Schabas, supra $+\mathrm{n} 113$ t at 254.

144 Janowiec and Others v Russia, supra (n 3 ) at Joint Concurring Opinion of Judges Kovler and Yudkivska.

145 Schabas, supra (n 113) at 257.

${ }^{146}$ Carozza, 'Subsidiarity as a Structural Principle of International Human Rights Law' (2003) 97 American Journal of International Law 38', at 38. 
should be first in seeking to resolve disputes of values among members of political communities. ${ }^{147}$ De Londras extends the conception of subsidiarity to include consideration not only by the Court and states, but also the political organs of the Council of Europe. This approach would allow "systemic or endemic rights violations to be tackled as a political matter, particularly since the judgments of the Court already handed down in relation to those violations have not been executed fully or in a manner that in fact addresses the violations in question", ${ }^{148}$ a claim which may have particular resonance in addressing the substance of transitional justice claims involving widespread or systemic rights violations. The Court has referenced the principle typically through Articles 1 (obligation to respect human rights), 13 (right to an effective remedy) and 35(1) (admissibility criteria) as the Convention bases for the principle of subsidiarity. ${ }^{149}$

Subsidiarity appears to cut both ways regarding the Court's approach to historical abuse. An emphasis on subsidiarity was reflected in the dissents in O'Keeffe, where the judges referenced the need to respect national and sub-national choices regarding the regulation of schools and education, ${ }^{150}$ suggesting subsidiarity could function in some instances to constrain the Court's engagement with historical abuse, especially involving regulation of non-state actors. In contrast, in El-Masri, while cautious regarding substituting its judgment for that of a national decision maker, the Grand Chamber took into account the quality of the domestic fact-finding procedures and found that Macedonia had not explained what had happened to the applicant and that his account, with supporting evidence, was established beyond reasonable doubt. Mowbray notes subsidiarity in this context was "not simply a device to constrain the Court." 151 In this regard one would expect to see continued incrementalism and pragmatism in the Court in any engagement with transitional justice issues as an element of its approach to subsidiarity, reflecting the need from emergent consensus

\footnotetext{
${ }^{147}$ von Staden, 'The Democratic Legitimacy of Judicial Review beyond the State: Normative Subsidiarity and Judicial Standards of Review' (2012) 10 International Journal of Constitutional Law 1023.

148 De Londras, 'Dual Functionality and the Persistent Frailty of the European Court of Human Rights' (2013) European Human Rights Law Review 38 A' (2013) 38 European Human Rights Law Review 38 , at 46.

${ }^{149}$ Mowbray, 'Subsidiarity and the European Convention on Human Rights' (2015) 15 Human Rights Law Review 313, at 319.

150 O'Keeffe $v$ Ireland, supra f $n$ 4) at Joint Partly Dissenting Opinion of Judges Zupancic, Gyulumyan, Kalaydjieva, De Gaetano and Wojtyczek, at para 7.

151 Mowbray $_{2}$ supra (n 149) $\underline{\text { at }} 332$.
} 
among states parties in appropriate responses to addressing historical abuse.

The irony is that respect for subsidiarity, which may result in a less active role for the Court in advancing transitional justice, may also align with the pursuit of local ownership of transitional justice processes. Transitional justice is a highly selfreflective field of scholarship and practice and remains vigilant regarding concerns for a neo-colonial or neo-imperial imposition of foreign legal norms and practices. ${ }^{152}$ It has led to consideration of the need for "bottom up" or locally owned process of dealing with the past. ${ }^{153}$ To the extent that the Court or Convention are used to override nationally and locally negotiated practices of transitional justice among victimsurvivors, such litigation would seem inimical both to transitional justice theory and to the Court's dynamic understanding of subsidiarity.

However, even on this more constrained basis, the Strasbourg Court may be uniquely placed among international human rights mechanisms to address historical abuse in a more coherent, albeit subsidiary, fashion through the use of its pilot judgment mechanism.

\section{THE LIMITATIONS OF INTERNATIONAL LAW TO ADDRESS GROSS VIOLATIONS OF HUMAN RIGHTS}

The European Convention system remains limited in its capacity to address widespread or systemic human rights violations. ${ }^{154}$ Its individual focus, which would inevitably be strained in addressing mass atrocity, is compounded by a judicial politics that inhibits explicit legal and political acknowledgement of widespread or systemic human rights violations by states parties, instead focusing on isolated cases. ${ }^{155}$ This

\footnotetext{
152 Bell, 'Transitional Justice, Interdisciplinarity and the State of the "Field" or "Non-Field"' (2009) 3 International Journal of Transitional Justice 5; Turner (n 19); Nagy, 'Transitional Justice as Global Project: Critical Reflections' (2008) 29 Third World Quarterly 275.

153 Lundy and McGovern, supra (n 20); McEvoy and McGregor (eds), Transitional Justice from below: Grassroots Activism and the Struggle for Change (Hart Pub 2008).

154 Kamminga, 'Is the European Convention on Human Rights Sufficiently Equipped to Cope with Gross and Systematic Violations?' (1994) 12 Netherlands Quarterly of Human Rights 153; Reidy, Hampson and Boyle, 'Gross Violations of Human Rights: Invoking the European Convention on Human Rights in the Case of Turkey', (1997) 15 Netherlands Quarterly of Human Rights 161.

155 Ní Aoláin, 'The Emergence of Diversity: Differences in Human Rights Jurisprudence' (1995) 19 Fordham International Law Journal 101.
} 
limitation mirrors a challenge acknowledged in transitional justice discourse, whereby it is inevitably impossible and perhaps undesirable for States to address widespread or systemic violence through the use of ordinary criminal law, which is designed to operate where the violation of law is the exception and not a large social phenomenon. ${ }^{156}$ In seeking to address this limitation, Fletcher argued for a reassertion of state, rather than individual, responsibility for mass atrocity and systematic violations of human rights. ${ }^{157}$ The innovative use of the Inter-American Court of Human Rights system contributed to the early practice of transitional justice in that region by enabling greater consistency and cross-pollination of the strategies and legal framework employed by post-authoritarian societies. However, this was a process that continued to rely primarily on individual litigants pursuing international State responsibility and one that relied on decades of slowly developed jurisprudence. ${ }^{158}$

The ECtHR system has one notable potential advantage in addressing gross and systemic human rights abuses, which may apply particularly well to historical abuse cases. Ní Aoláin notes "the launch of the pilot procedure by the Court, to address socalled repetitive cases deriving from a common dysfunction at the national level, can

156 Aukerman, 'Extraordinary Evil, Ordinary Crime: A Framework for Understanding Transitional Justice' (2002) 15 Harvard Human Rights Journal 39.

${ }_{157}$ Fletcher, 'A Wolf in Sheep's Clothing? Transitional Justice and the Effacement of State

Accountability for International Crimes' (2015) 39 Fordham Internationa'- Law Journal 447.

${ }_{158}$ Sikkink, The Justice Cascade: How Human Rights Prosecutions Are Changing World Politics (1st

ed., WW Norton \& Company 2011). 
be seen as responsive to the structural challenges of absorbing new democracies." 159 The accession of former Soviet republics "partially changed the role of the Strasbourg Court from fine-tuning situations in relatively stable and functioning societies to having to deal with large-scale and systemic human rights problems." 160 This shift in the Court's role exacerbated existing problems involving numerous and repetitive applications, often involving Turkey, Russia and Italy. In 2011 the ECtHR codified the pilot judgment procedure, defining its elements as being to identify a structural or systemic problem or other dysfunction, point out the type of domestic remedies the respondent is required to develop and indicate such measures in the operative parts of the judgment. ${ }^{161}$

The pilot judgment procedure seems particularly apt to address historical abuse claims involving classes of potential applicants and to enable the design and implementation of effective State mechanisms to investigate and redress historical abuse coherently. Its potential seems suitable to historical abuse both within and beyond the contexts of armed conflict or authoritarian rule, but the Court's emergent practice suggests the need for cautious optimism at best - pilot judgments retain potential but are not a panacea to addressing historical abuse. In Broniowski v. Poland, the ECtHR first considered the use of pilot judgments in the context of the right to compensation of

\footnotetext{
159 Ní Aoláin, supra (n 6), at 20.

160 Buyse, 'Airborne or Bound to Crash? The Rise of Pilot Judgments and Their Appeal as a Tool to Deal with the Aftermath of Conflict', in Buyse (ed) Margins of Conflict: The ECHR and Transitions to and from Armed Conflict (Intersentia 2011) 196.

${ }_{161}$ Rule 61, inserted by the Court on 21 February 2011: see ECtHR, Rules of Court, 1 July 2014.
} 
those historically displaced from Poland by the expansion of the Soviet Union. ${ }^{162}$ The Grand Chamber held that the violation of property rights occurred as part of a larger problem and "originated in a widespread problem which resulted from a malfunctioning of Polish legislation and administrative practice and which had affected and remains capable of affecting a large number of persons". ${ }^{163}$ The Court noted that 167 similar cases were pending and that over 80,000 people were affected by a lack of compensation. The Grand Chamber concluded that, in remedying the situation, the State should take general appropriate legal and administrative measures to address the whole group of affected claimants, designed to "either remove any hindrance to the implementation of the right of the numerous persons affected by the situation found, in respect of the applicant, to have been in breach of the Convention, or provide equivalent redress in lieu." 164

The Grand Chamber interpreted Article 46, whereby State Parties are legally bound to abide by the final judgment of the Court in any case to which they are parties, as giving states parties some discretion in the means chosen to discharge their obligations, provided such means are compatible with the conclusions set out in the

\footnotetext{
162 Broniowski v Poland Application Nno 31443/96 Judgment 22 June 2004).

163 ibidlbid.; at para $=189$.

164 ibidllbid.; at para- 194.
} 
Court's judgment. ${ }^{165}$ Buyse emphasises the need for caution when considering the application of a pilot judgment procedure to cases involving widespread or systemic human rights abuses: "implementation of such a pilot judgment does depend on the executive in the end. Truly unwilling authorities will not be convinced to change their actions. In that sense, no magic can be expected from Strasbourg." 166 However, the Strasbourg Court's judgments may add to domestic political and legal pressure on an executive and must be understood not merely in formal legal, but also in socio-legal and political terms. In the context of historical abuse, some states parties have already demonstrated a degree of commitment to acknowledging and addressing a legacy of prior historical human rights violations.

The effective exercise of this oversight by the Court and the Committee of Ministers remains critical and, based on the limited practice regarding pilot judgments to date, could be enhanced by greater engagement with the widespread problem that generates the the pilot judgment. Room to improve is evident from the approach in

\footnotetext{
165 Ibid. at para 192.

166 Antoine C-Buyse-(ed), Margins of Conflict: The ECHR and Transitions to and from Armed Conflict (Intersentia; Distribution for the USA and Canada, International Specialized Book Services 2011),
} supra n 160, 190. 
Dogan $v$ Turkey. ${ }^{167}$ The case concerned the forced eviction of Kurds from their village in Turkey. 168 The ECtHR ruled that Turkey violated Article 13 due to its failure to conduct an effective investigation and to provide a remedy by which the applicants could challenge the authorities. While the Court had addressed similar issues previously, Kurban suggests this case, although not referred to explicitly as a pilot judgment, is distinctive and replicates many of the features of explicit pilot judgments, as it names the protracted problem as 'the situation of the internally displaced persons' in Turkey and explicitly influenced the Turkish government's drafting of a new compensation law for property expropriation. ${ }^{169}$ Kurban is critical of the Court's approach in the subsequent Turkish case of Icyer, where Turkey demonstrated this new law had resulted in " 170,000 applications nationwide and a 'substantial number of sample decisions' issued mostly by the Tunceli and Diyarbakır Commissions, awarding over 31,000 Euros per applicant, which led the Court to conclude that the remedy was accessible and provided 'reasonable prospects of success'."170 As a result the Court recognised the compensation law as an effective remedy, and dismissed over 800 related cases, but failed to address the rejection of a significant number of applications to the scheme and the reduced level of compensation when compared with the award in Dogan. ${ }^{171}$ This experience calls into question the generalizable nature of the pilot judgment as a mechanism to address widespread or systemic abuses. Kurban notes that pilot judgments may remain ineffective if they are unable to address the underlying cause of dispute or structural violence, in these cases "the Kurdish question, a deep rooted, ethno-political conflict."172 Similar concerns could arise in the context of historical abuse in peaceful democracies, if pilot judgments were used to address legislative solutions to addressing the past only, while ignoring the rights violations that contributed to historical marginalisation and wrongdoing more generally. - If the pilot judgment system has the primary consequence of alleviating Court's case backlog, rather than alleviating the harms

\footnotetext{
${ }^{167}$ Kurban, 'Forsaking Individual Justice: The Implications of the European Court of Human Rights' Pilot Judgment Procedure for Victims of Gross and Systematic Violations' (2016) 16 Human Rights Law Review 731.

${ }^{168}$ Dogan and Others $v$ Turkey Applications Nos 8803-8811/02 et al, Merits and Just Satisfaction, 29 June 2004.

169 Kurban supra (n 167) at 741-2.

170 ibid 752.lbid. at 752.

171 ibid $753-4$.lbid. at 753-4.

172 lbid. at 768 .
} 
suffered by victim-survivors of widespread human rights abuses, it will not be seen as a legitimate alternative to individualised applications and justice.

\section{CONCLUSION}

The European Court of Human Rights has developed a robust jurisprudence regarding states parties' commitments to investigate, prosecute, redress victims and prevent reoccurrence of human rights abuses, which can be framed as part of a transitional justice paradigm. The recent El-Masri decision confirms that the Court is interested in adopting the language and rights of transitional justice such as the right to truth, but in a cautious and incremental way that seeks to respect the Court's subsidiary role in human rights protection The Court has also cautiously addressed the historical or inter-temporal application of the Convention in O'Keeffe and Janowiec, enabling State liability in O'Keeffe for a historical failure to prevent child sexual abuse within the critical date for Ireland, while offering a somewhat unsatisfactory rejection of jurisdiction in Janowiec that nonetheless enables the potential extension of Convention jurisdiction ten years beyond the critical date of Convention adoption by member States. 